\title{
Transport and modification of glaciovolcanic glass from source to sink on Mars
}

\section{S.J. de Vet}

Earth Surface Science, Institute for Biodiversity and Ecosystem Dynamics, University of Amsterdam, Science Park 904, 1098 XH Amsterdam, the Netherlands. Email: s.j.devet@uva.nl

Manuscript received: 12 July 2014, accepted: 13 February 2015

\section{Abstract}

Spectral observations show that volcanic glass is the dominant ingredient of the aeolian landforms which cover the northern lowlands on Mars. Surface winds subject these sands to physical alteration processes in the present-day surface environment. This work highlights the role of glaciovolcanism throughout Mars' geologic history and the parallels with landforms and materials found in Iceland. As the physical properties of Martian volcanic glass particles are difficult to constrain from orbit, Icelandic materials can provide valuable insights in their transport and modification characteristics. The processing of glass grains by environmental processes by means of the dune transport cycle is discussed. Experiments targeted the grain-size alteration effects experienced during the dune transport cycle, including the effect of 'low-energy' avalanching and 'highenergy' aeolian regimes (i.e. particle rolling and saltation). Saltation transport was found to rapidly alter grains and particle size distributions, which contributes to a positive feedback loop where the new smaller grains are mobilised more easily after fracturing and surficial abrasion. Postdepositional physical alteration therefore needs to be reconciled with the present-day silicic spectral signatures of these glasses in order to infer the relevant landform genetic. This effort is especially relevant in respect to the loss of possible signatures of biochemical alteration from microbial interactions, as glaciovolcanic environments are favourable habitats for life. As chemical and physical weathering is limited to the grain exterior, the grain interior may still retain a geochemical record of the subglacial eruption environment in which these grains were formed. Quantification of the volatiles sequestered in the glass can therefore be used to identify the formative conditions of the amorphous component in aeolian sediments.

Keywords:: abrasion, saltation, subglacial volcanism, volcanic glass, wind tunnel

\section{Introduction}

Fragmental volcanic glass, or hyaloclastite, is formed by fragmentation and rapid syneruptive quenching of magma with melt water underneath or in contact with subsurface and surface ice (Jakobsson \& Gudmundsson, 2008; Russel et al., 2014). A substantial deposit composed of volcanic glass covers $\sim 10^{7} \mathrm{~km}^{2}$ of the northern lowlands on planet Mars (Carozzo et al., 2012; Horgan \& Bell, 2012a). This dark albedo feature is indigenous to vast dune systems where winds mobilise glassrich sediments (Hansen et al., 2011; Bridges et al., 2012a; Horgan \& Bell 2012b). The transfer of kinetic energy during aeolian transport can induce surficial alterations and grain-size reduction processes through the process of grain fracturing. Depending on particle shape and impact velocity, such alteration can vary from physical to pseudochemical and even mineralogical alterations (e.g. Merrison et al., 2011; Marshall et al., 2012).
However, the physical properties of volcanic glass grains are still difficult to constrain from orbit. Particle size estimations based on thermal inertia (e.g. TES on 1996 Global Surveyor and THEMIS on 2001 Mars Odyssey) are influenced by sediment induration, crusting and other complicating grain properties, causing overestimations of particle sizes (Kirkland et al., 2003). Thermal inertia currently suggests particle sizes larger than expected for Mars (400-500 $\mu \mathrm{m})$, which is supported by the particle sizes observed at the surface by lander and rovers (100$300 \mu \mathrm{m}$; Sullivan et al., 2008). These factors complicate the interpretation of the silicic, almost obsidian-resembling spectral signature of the basaltic glass deposits, especially in relation to syneruptive or post-eruptive environmental reworking and understanding how grain properties affect thresholds for sediment mobility. The characterisation of the environmental fate of these glasses using terrestrial analogue materials (i.e. geologic substitutes) therefore provides an important first step 
in understanding the dynamics of these granular materials at the surface of Mars. This work aims to provide a synthesis of several experimental studies which aimed to understand how glassy materials are formed and how they are subsequently modified by aeolian processes on Mars. Here the significance of glaciovolcanism on Mars and its parallels with eruptions and landforms in Iceland is outlined first. Subsequently, wind detachment thresholds based on wind tunnel experiments that are instrumental for driving grain alteration are discussed. These alteration effects of different aeolian regimes and their effectiveness for particle modification are then discussed.

\section{Glaciovolcanism on Mars}

Glaciovolcanism embodies all possible interactions of erupting magma with ice, varying from glacial ice to surface and subsurface ground ice (Smellie, 2006, 2007). Numerous landforms illustrate that glaciovolcanism has played an important role in shaping the surface of Mars. Constructive volcanic mesas known as tuyas (Fig. 1A,B) are found across a large variety of latitudes, ranging from volcanic fields near the poles to areas once covered by tropical mountain glaciers (Allen, 1979; Ghatan \& Head, 2002; Head \& Wilson, 2007; Hovius et al., 2008; Fagan et al., 2010; Martínez-Alonso et al., 2011; Scanlon et al. 2014). 0ther common features include ridges known as tindars (Wilson \& Head, 2002; Chapman et al., 2003; Komatsu et al., 2004; Zealey, 2009; Pedersen et al., 2010), which dominate in the neovolcanic zones of Iceland (Jakobsson \& Gudmundsson, 2008). With the exception of the subaerial lavas, both tuyas and tindars contain comparable facies (Fig. 1C). Pillow lavas are found at the base of subglacial edifices, superposed by breccias composed of volcanic glass. The in situ alteration of basaltic glass by the process of palagonisation following the Surtsey (Jakobsson, 1978; Jakobsson \& Moore, 1986) and Gjálp (Jarosch et al., 2008) eruptions in Iceland illustrate how edifices composed of fragmental volcanic glass are transformed into erosion-resistant features within the first 1-2 years after eruption. If the eruption is of sufficient volume or longevity, it will be able to melt its way upwards through the overlying ice body. In the overall stratigraphy of the edifice (Fig. 1C), the passage zone marks the level of the intraglacial lake formed by melting of the overlying ice. The summit plateau forms during the subaerial phase and provides an indication of the glacial thickness, usually within an accuracy of $100 \mathrm{~m}$ for the largest edifices (Licciardi et al., 2007).

A large diversity of glaciovolcanic landforms are found at the Martian surface across a variety of latitudes and epochs (Fig. 1D) and attest to the importance of these eruption environments over a large part of Mars' geologic history. Of these features, tuyas are the most easily identifiable due to their characteristic morphometry (Keszthelyi et al., 2010) and they assume an important role as they are the most tell-tale remnants of these past environments on Mars. As tuyas are in essence erosion-resistant scale markers of the ice bodies in which they formed, their morphometry can also be used to infer palaeo-ice thicknesses. Ice thickness is a useful proxy for quantifying the confining glaciostatic pressure inside the eruption cavity during the eruption, which drives the transition from pillow lavas to fragmental volcanic glass (Tuffen, 2007). A simple comparison of confining pressure regimes on Mars and in Iceland is provided in Fig. 2. Here, glaciostatic pressures are based on Martian tuya heights (Fagan et al., 2010) and Icelandic edifices (Licciardi et al., 2010) using, respectively, densities of Martian polar ices (Zuber et al., 2007) and terrestrial glacial ice $\left(850 \mathrm{~kg} \mathrm{~m}^{-3}\right)$. Fig. 2 therefore illustrates that the range of confining cavity pressures on Mars overlaps those of eruptions in Iceland. From the standpoint of comparable formative conditions, this overlapping range supports the use of fragmental glass from Iceland as a geologic substitute for volcanic glass on planet Mars.

The glaciovolcanic environment also plays an important role in how these materials are transported and emplaced, which is distinctly different from other types of volcanic eruptions. For example, the eruption characteristics of sub-ice and sub-marine eruptions are comparable, yet the confinement of an eruption by an ice body sets subglacial eruptions apart from sub-marine variants in terms of access of water to the volcanic vent and drainage of the eruption cavity (Moore \& Calk, 1991; Smellie, 2006). During the 1963-1967 submarine eruption at Surtsey, situated at the southern extremity of the Southern Volcanic Zone in Iceland, no appreciable fluvial transport of glassy materials by local sea currents was observed and materials were deposited in close proximity to the eruption vent (Kokkelaar \& Durant, 1983). Syneruptive Jökulhlaups, catastrophic glacial outburst floods of generated meltwater, are capable of mobilising and transporting large quantities of basaltic glass. Similar fluvial processes in response to glaciovolcanic eruptions may have come into play for the emplacement and concentration of these materials at the topographic low of Mars' northern hemisphere, where many outburst flood channels and hydrological networks terminate (Horgan \& Bell, 2012a). The lack of substantial geothermal gradients in situ in the northern lowlands needed to drive further palagonisation of these sediments may have prevented substantial induration and consolidation of these materials after deposition. Since their emplacement, surface winds have reshaped these deposits into an extensive sand sea indigenous to numerous dune systems.

\section{Experimental methods and results}

Active aeolian processes (Hansen et al., 2011; Bridges et al., 2012a; Horgan \& Bell 2012b) currently contribute to the mobilisation and reworking of glass-rich sediments in the northern lowland dunes. In the dune transport cycle (Fig. 3) we can discriminate between four different stages: wind-induced 

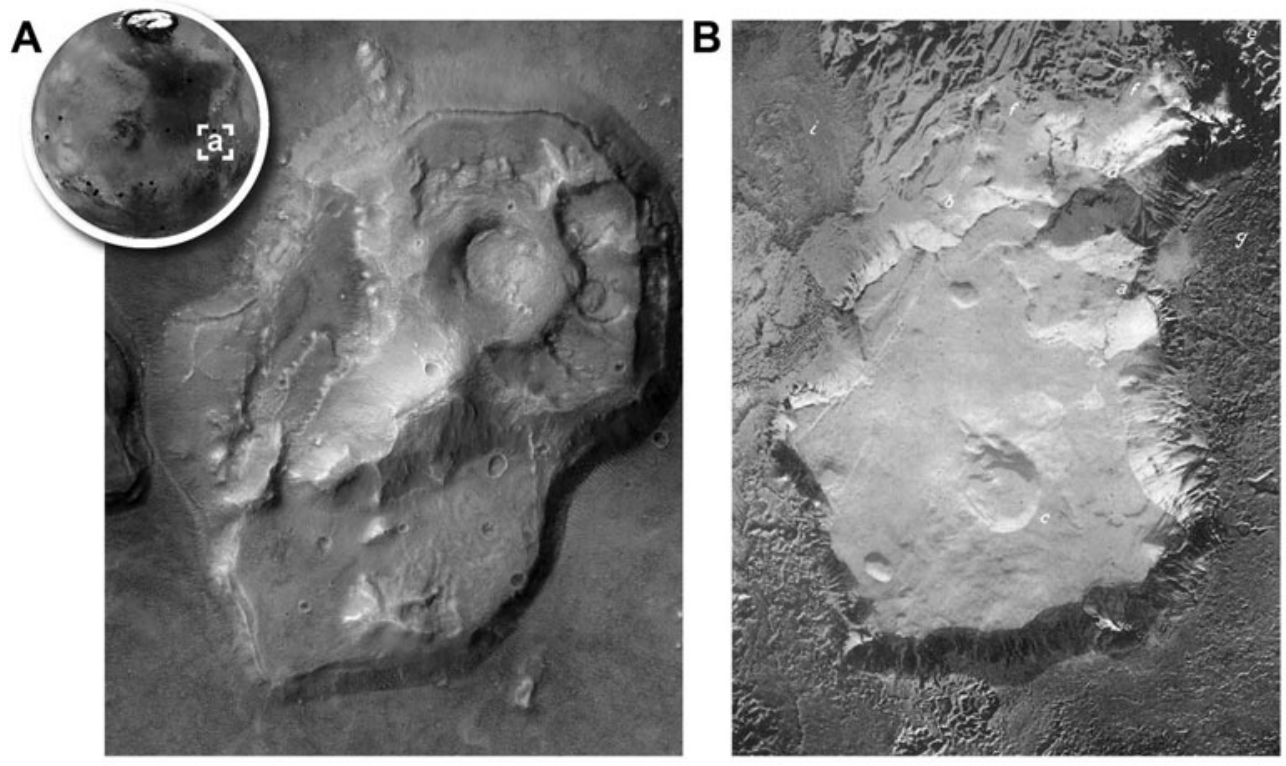

C

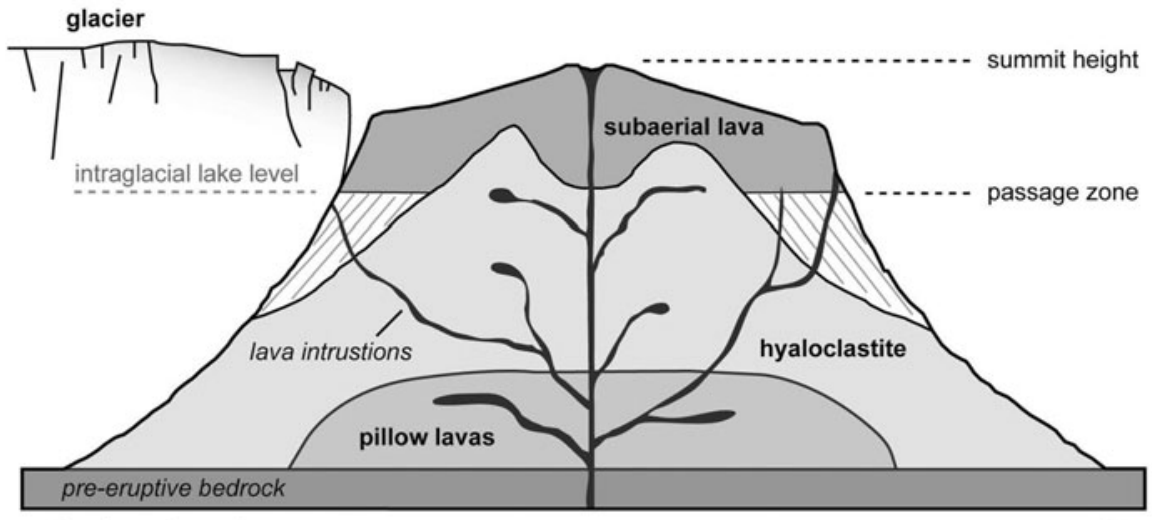

at the time of eruption

present-day

D

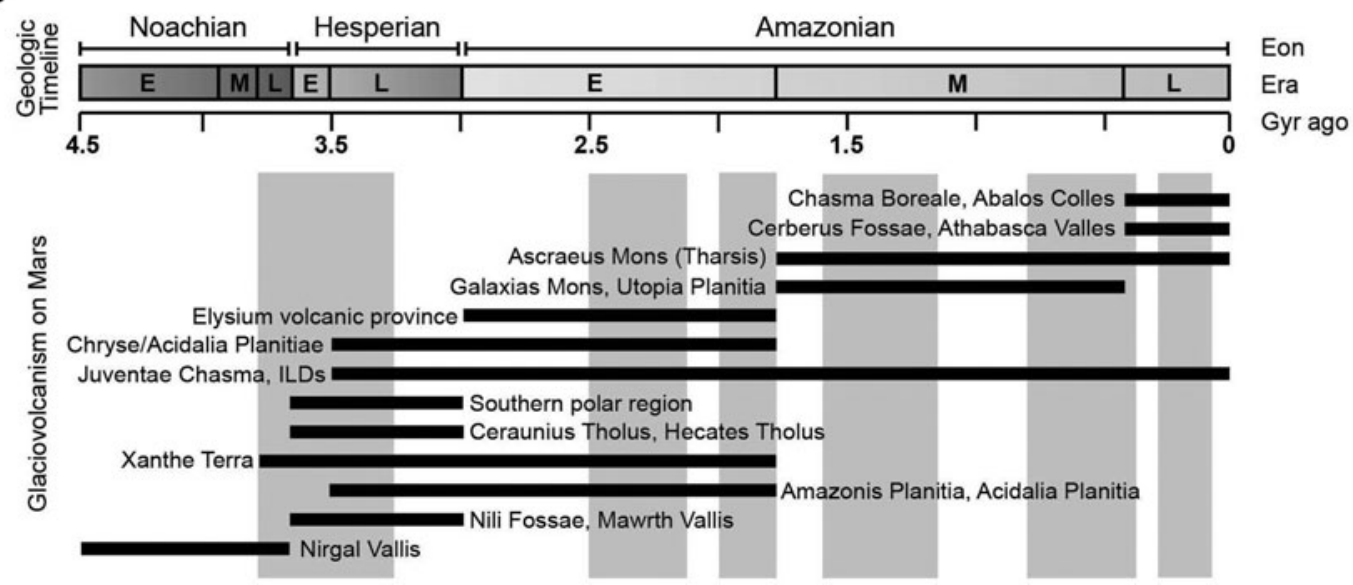

Fig. 1. Glaciovolcanic features on Mars. A. Constructive volcanic mesas, such as this putative tuya in the Western Cydonia Region in Acidalia are indicative of subglacial volcanism (HiRISE image PSP_008574_2210; NASA/JPL/University of Arizona). B. These edifices share many generic features with terrestrial sub-ice volcanoes, such as the Gæsafjöll tuya in northern Iceland (from: van Bemmelen \& Rutten, 1955). C. Diagnostic units of tuyas include subaerial summit plateaus and crater vent, which superpose glassy breccias known as hyaloclastites (adapted from: Jakobsson \& Gudmundsson, 2008). D. The formation of glaciovolcanic landforms during Mars' geologic history (black horizontal bars; Cousins \& Crawford, 2011) is favoured by coinciding peaks of volcanic and glacial activity (grey vertical bars; Neukum et al., 2010). 


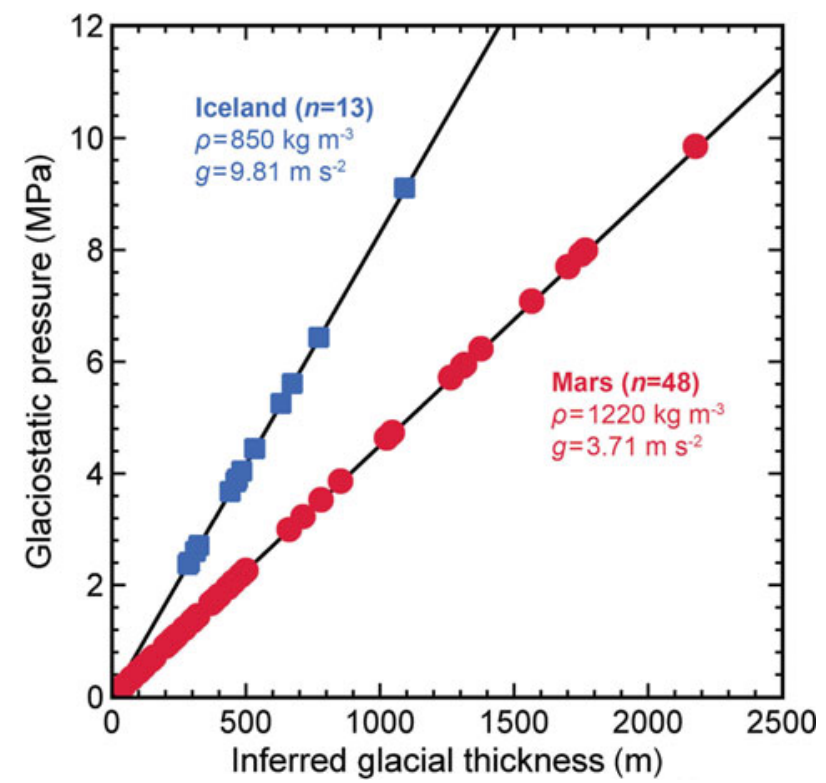

Fig. 2. Maximum confining glaciostatic pressures on Earth (blue) and Mars (red). Glaciostatic pressures ( $p_{\text {ice }}$ ) are given by $p_{\text {ice }}=\rho_{\text {ice }} g h$, where $\rho_{\text {ice }}$ is the ice density, $g$ is the gravitational acceleration and $h$ is the inferred glacial thickness. Pressures are inferred using the edifice heights of Icelandic tuyas (black; from Licciardi et al., 2007). Pressures of Martian polar and equatorial tuyas are based on edifice heights from Fagan et al. (2010) and on orbital measurements of polar ice densities by Zuber et al. (2007). Although the actual confining pressures are generally lower than those calculated using edifice height, eruption cavity pressures that control magma fragmentation are of a similar order of magnitude on both planets.

detachment of sand grains, transport by saltation, downslope avalanching and subsequent burial of the sediment. The integration of several experimental studies, discussed in greater detail below, targets these facets (with the exception of burial) of the transport cycles for quantifying effects of grain alteration during aeolian transport.

\section{Wind tunnel detachment experiments}

The first phase of the dune cycle is the detachment of individual sand grains. Many observations have shown that sand transport is a common, if not perhaps the most common, active geomorphic process on Mars (Sullivan et al., 2005, 2008; Fenton, 2006; Bourke et al., 2008, 2010; Silvestro et al., 2010, 2011; Chojnacki et al., 2011; Hansen et al., 2011; Bridges et al., 2012a; Gardina et al., 2012; Horgan \& Bell, 2012b) with sediment fluxes comparable in magnitude to terrestrial dune systems (Bridges et al., 2012b). The shear stress $(\tau)$ required for grain detachment at the fluid threshold is dependent on the density of the atmosphere $(\rho)$ and the square of the friction velocity $\left(u_{*}\right)$. The low-density state of the atmosphere $\left(0.02 \mathrm{~kg} \mathrm{~m}^{-3}\right)$ thus requires much higher wind speeds in comparison to Earth $\left(1.2 \mathrm{~kg} \mathrm{~m}^{-3}\right)$. The rarity of the required wind speeds and observations of high aeolian activity at the Martian surface high- light the continuous and paradoxal nature of dust and sand transport on present-day Mars. Experimental aeolian studies have therefore focused traditionally on quantifying the thresholds for detachment of sand grains through the process of saltation; the rapid ballistic return of sand grains to the surface, hereafter referred to as 'entrainment'. Several frontier studies of Martian aeolian processes have used wind tunnel experiments in low-density atmospheric conditions comparable to Mars for establishing entrainment thresholds (Greeley et al., 1974, 1980; Iversen et al., 1976; Iversen \& White, 1982; Greeley \& Iversen, 1985). More recent numerical studies of the phenomenon indicate that saltation is easy to sustain on Mars as the impact threshold requires much lower wind speeds (Kok 2010a,b; Kok et al., 2012), although grains still need to detach first at the higher fluid threshold. This paradoxal aspect of initiating sand mobility has been left partly unresolved by early wind tunnel studies as their set-ups have been ineffective for observing the first moments of particle detachment. The first type and moment of grain detachment has been frequently observed to have a rolling/rocking component, which results from the vertical flow gradient across the height (diameter) of a single sand grain (Reeks \& Hall, 2001; Ibrahim et al., 2004, 2008). Different types of wind tunnel studies were therefore performed by de Vet et al. (2014b) using a hypobaric wind tunnel (Fig. 4) to study this rolling effect for the detachment thresholds of vesicular volcanic glass grains. Semi-empirical models developed from the experimental studies by Merrison et al. (2007) and de Vet et al. (2014b) have been combined in Fig. 5 to delineate the flow regimes for grain detachment and entrainment at fluid threshold conditions on Mars. Both studies targeted the extremes of possible glass grain morphologies; Merrison et al. (2007) used spherical glass particles akin to those of aeolian mature glass grains, while de Vet et al. (2014b) used juvenile vesicular glass grains. In Fig. 5 the upper shear stress on the axis $\left(0.3 \mathrm{~N} \mathrm{~m}^{-2}\right)$ is based on the wind flow conditions inferred from saltation ripples on the stoss of Martian dunes (Sullivan et al., 2005; de Vet et al., 2014b). Model predictions in Fig. 5 suggest the detachment by rolling is an effective precursor and potential trigger for saltation at the fluid threshold as it takes place at lower wind speeds (i.e. wind shear stress). This makes detachment by rolling an instrumental process for explaining the initiation of saltation at lower, and as such commonly recurring, wind speeds in the low-density atmosphere of Mars.

\section{Particle abrasion experiments}

Once fluid threshold conditions are met and grains detach, saltation is triggered and sustained, causing the aeolian system to transit to impact threshold conditions. Under these conditions, grain impacts during saltation and reptation start to transfer their kinetic energy to stationary grains at the bed. Marshall et al. (2012) studied the types of grain alteration as a consequence of grain-grain interaction in different aeolian 
Fig. 3. The sand transport cycle of sand grains inside a dune. During wind conditions at and above the fluid thresholds $(A)$, particles are detached and will move along ballistic trajectories (known as saltation) across the stoss of the dune. At the crest of the dune, grains will avalanche down-slope across the slip face (B) where they are buried until dune migration (C) has progressed enough for the grains to re-enter the transport cycle (D).

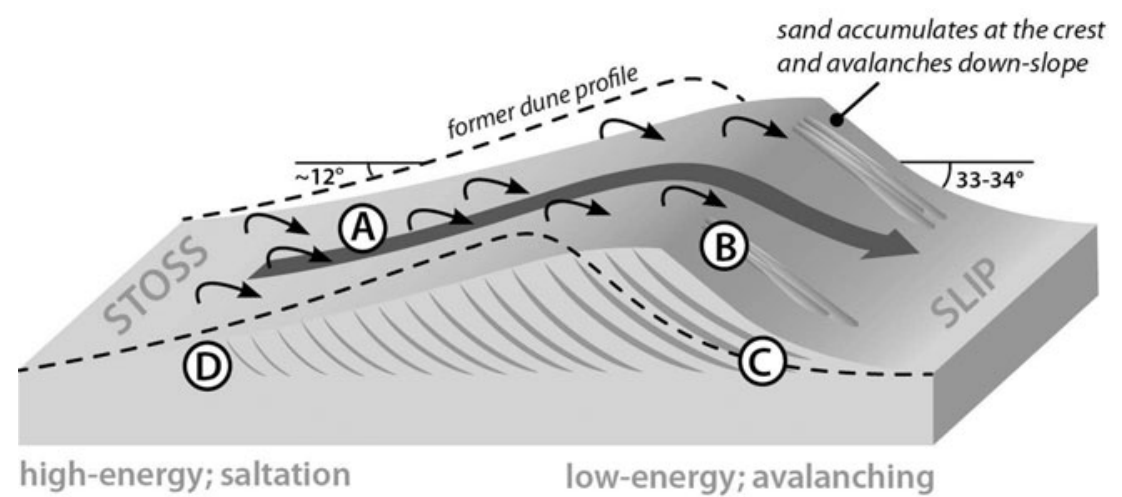

high-energy; saltation low-energy; avalanching energy regimes. Grain fracturing and textural development of the grain surface appeared not to have a simple relationship to grain impact velocity, but were found to scale with the energy expended within the contact area formed by elastic deformation during grain-grain impacts (Marshall et al., 2012). Grain alterations experiments were set up to study the effects of such saltation impacts on the evolution of particle size distributions (PSDs) as the foremost proxy for sediment alteration during cycling of sediment in a glass-rich dune system. Two types of experiments aimed to simulate the effects of low-energy avalanching at the slip face and high-energy impacts during saltation and reptation of grains at the stoss (Fig. 3).

A rock tumbler set-up was used for the avalanching experiments (Fig. 6A). In these experiments a 300-600 $\mu \mathrm{m}$ sieved fraction of silicic volcanic glass from Iceland was subjected to $\sim 700 \mathrm{~km}$ of avalanching (de Vet et al., 2014a), which represents a multitude of avalanche events across the slip face of a dune. The PSDs were measured before and after the avalanching treatment of six independent glass samples in duplicates (i.e. providing $n=12$ measurements). The samples were pre-treated with $\mathrm{Na}_{4} \mathrm{P}_{2} \mathrm{O}_{7} .10 \mathrm{H}_{2} \mathrm{O}$ for brining all clay- to silt-sized grains into suspension (Eshel et al., 2004); PSDs were subsequently measured using a Sympatec HELOS laser diffraction particle sizer. The results of these experiments are shown in Fig. 7A, where little to no difference between the two PSD curves illustrates that avalanching across the slip face has little influence on the overall modification of grains.

High-energy grain impact experiments were performed with three grain sizes using a particle vortex chamber (Fig. 6B) based on the device used by Marshall et al. (2012). Compressed air was fed into the device and the outflow of compressed air jets was calibrated with a wind-flow sensor to obtain the desired wind speed (which was taken as the grain impact speed). For 100$300 \mu \mathrm{m}$, a size range common for present-day aeolian sediment on Mars, the duration of the treatment per wind speed was scaled such that the added aeolian energy (i.e. the accumulated grain impact kinetic energy) was constant for each experiment. Scaling was performed using the formula $2 / 3 \pi r^{3} \rho v^{2} t$, where $r$ is the grain radius, $v$ is the grain impact speed, $\rho$ is the density
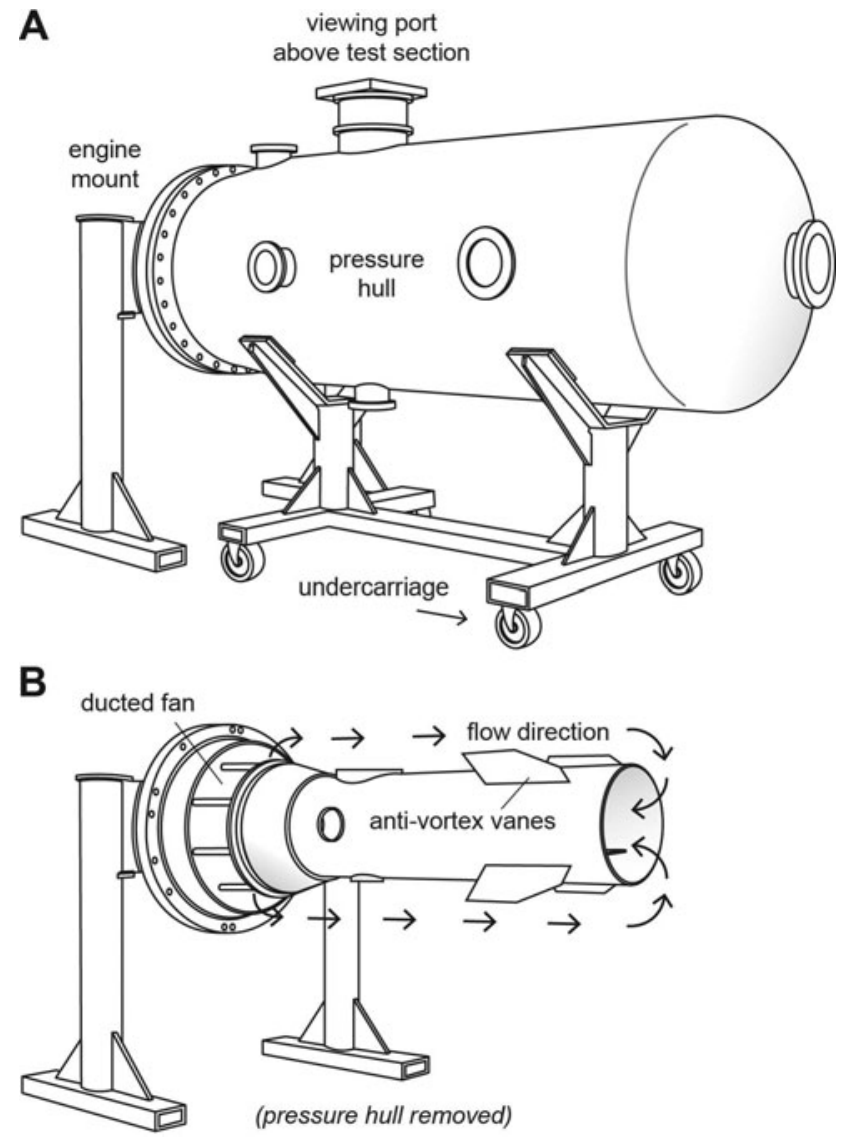

Fig. 4. The Aarhus Wind Tunnel Simulator used for the wind tunnel experiments. The turbulent-flow wind tunnel employs a recirculating design; the test section is enclosed inside a 3-m long pressure hull $(A)$ that allows the atmospheric density to be varied by lowering the pressure or by altering the gas mixture and temperature. Removal of the pressure hull exposes the main flow section of the tunnel (B), which has a length of $1.5 \mathrm{~m}$ and $a$ diameter of $0.4 \mathrm{~m}$. Sample placement is possible through the porthole above the test section, which facilitates, once closed off by a $5 \mathrm{~cm}$-thick optically clear polycarbonate plate, monitoring of the wind-induced detachment of sediment deposits. More details on the AWTS are provided in Merrison et al. (2008). 


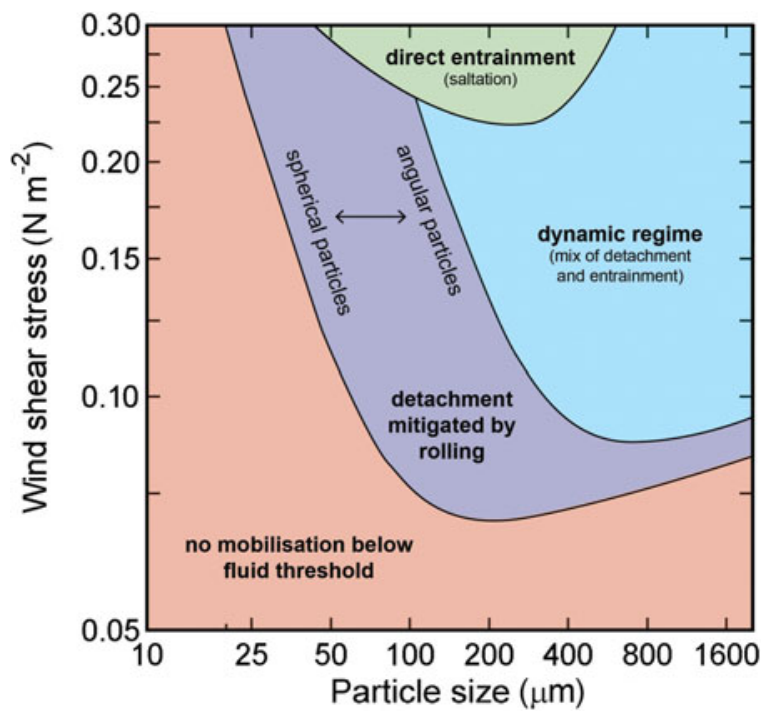

Fig. 5. Phase diagram differentiating between fluid thresholds of various particle detachment regimes on Mars. Detachment by rolling is based on model predictions from wind tunnel experiments with spherical and angular volcanic glass particles as the two morphological extremes (Merrison et al., 2007; de Vet et al., 2014b). Direct entrainment (i.e. saltation) is delineated using the same model prediction, but excluding the effects of detachment by rolling. The dynamic regime between detachment and direct entrainment therefore highlights the wind conditions during which grains transit from roll to pure saltation.

of the grain and $t$ is the duration of treatment (Marshall et al., 2012). The chosen experimental design resulted in treatments of $18 \mathrm{~h}$ at $2 \mathrm{~m} \mathrm{~s}^{-1}, 4.5 \mathrm{~h}$ at $4 \mathrm{~m} \mathrm{~s}^{-1}$ and $2 \mathrm{~h}$ at $6 \mathrm{~m} \mathrm{~s}^{-1}$. The wind speed and duration of the 300-600 $\mu \mathrm{m}$ and 1400-2000 $\mu \mathrm{m}$ samples were kept the same such that these resembled mobilisation by saltation and reptation at impact threshold conditions during similar wind-flow events. The chosen impact speeds are also in good agreement with numerical simulations of the terminal velocities of saltating grains under impact threshold conditions on Mars (Kok et al., 2012). PSDs were measured for each treatment in three triplicates (i.e. $n=9$ per curve) according to the same method as described for the avalanching experiments. The results of these experiments are shown in Fig. 7B-D and illustrate the effectiveness of saltation for inducing rapid grain alteration and physically driving the particle size evolution of glass-rich aeolian sediments.

\section{Discussion and perspectives on Mars}

Basaltic volcanic glass represents one of the single most important, geomorphic active types of surface sediments on Mars today. Although basaltic sands and glass have been suggested previously as analogue materials (e.g. Allen et al., 1981), the abundance of glass dunes warrants reappraisal of this material due to its unique spectral signatures and geomorphic evidence of its alteration in Mars' present-day surface environment.
Based on the experimental approaches described in this paper, several caveats can be placed on the interpretation of these materials on Mars, their use in experiments and the definition of future avenues for research.

\section{Grain alteration and spectral signature}

Detachment of grains represents the first step in the dune transport cycle, which takes place in the range of the upper limit of wind shear stress of $0.1-0.3 \mathrm{~N} \mathrm{~m}^{-2}$ inferred from the interspacing of ripples on dunes. Ripples are commonly formed during sustained saltation, reptation and splashing of grains at impact threshold conditions (Kok et al., 2012). The thresholds in Fig. 5 represent detachment at the higher fluid threshold. As detachment through rolling occurs at shear stresses lower than those inferred from ripples, it illustrates how the first moment of detachment can occur at much lower and more commonly recurring winds than suggested by some geomorphic features. This has important consequences for grain alteration as well. In the experimental treatment of grain alteration, the duration and wind speeds were dimensioned such that added aeolian energy would be comparable between the different grain sizes used. A notable difference was the effect observed at low-impact speeds with the longest treatment duration, which effected the largest changes to the sediment's PSDs. This effect was also found for all studied grains sizes. Alteration is probably driven by two competitive processes which contribute unevenly to the net sediment evolution. Whole-grain fracturing during (highenergy) impacts rapidly alters both sand grains and the mean particle size of the sediment (Greeley \& Iversen, 1985). This is well illustrated by the fracturing of the 1400-2000 $\mu \mathrm{m}$ grains, which induced a shift of the sediment's mode towards the 100$300 \mu \mathrm{m}$ range. In contrast, surficial fracturing processes appear to be more persistent in the chipping of the particle surface; producing less drastic alterations to the sediment's mode and more gradual shifts of the overall PSD. In this process the type of surficial chipping is strongly dependent on the particle's shape (Marshal et al., 2012). Based on the patterns in Fig. 7A reasonable inference is that the main driver of PSD evolution is not the cumulative aeolian energy per se (a low-speed, longduration treatment induces a stronger shift in the PSD then an equal-energy treatment at a higher-speed, shorter-duration), but rather the quantity of grain interactions due to the longer treatment period. If the duration of sand transport is indeed responsible for grain alteration, detachment and entrainment at lower and as such frequently recurring winds on Mars will subject aeolian grains to a substantial dose of alteration events. Aeolian alteration processes ultimately contribute to a positive feedback loop where detachment and entrainment of the grains becomes easier with steadily decreasing grain size and rounder shape.

The effective alteration in the short timespans of the experiments illustrates how aeolian transport of sediment over 
A

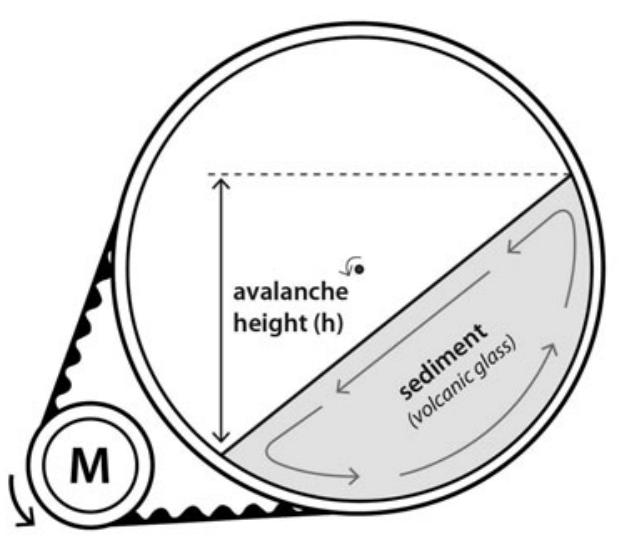

B

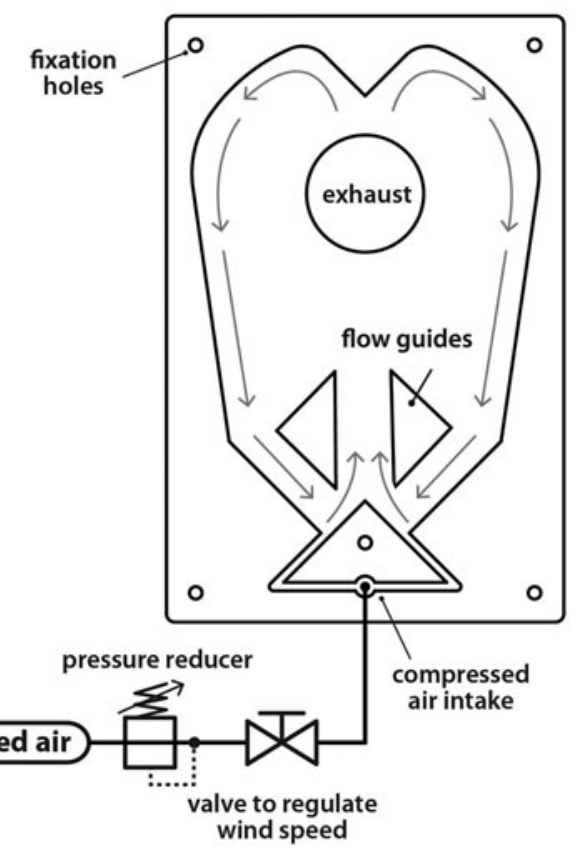

Fig. 6. Schematic overview of experimental set-ups for studying the effects of aeolian transport regimes on particle modification. A. Continuous rolling and granular avalanching of grains inside rotating drums can mimic several hundreds of kilometres of transport in a matter of weeks. B. The particle vortex chamber can be used to study the effects of particle impacts during saltation transport and offer greater control of air flow to dimension impact velocities on (e.g. Martian) aeolian energy regimes. Grey lines trace the approximate particle trajectories in these set-ups.

geologic time can significantly modify the exterior of aeolian grains. The effects of aeolian transport on glass grains are evidenced on Mars by the well-rounded grain morphologies observed by microscope imagers deployed by various landers (Goetz et al., 2010; Blake et al., 2013). However, the observed effectiveness of aeolian transport in altering PSDs also calls into question the exact origins of the silicic spectral signatures of weathered basaltic glasses on Mars. Observations of rinds with comparable spectral properties of basaltic glasses from Hawaii indicate that acidic leaching commonly produces rinds of several micrometres thick (Minetti et al., 2007; Chemtob et al., 2010; Seelos et al., 2010). If the rate of alteration in the experiments (Fig. 7) is a valid indication, aeolian abrasion of grains can easily strip the grain exterior of this silicic layer within several transport events. The acidic leaching proposed by Horgan \& Bell (2012a) as the main cause of the spectral signatures is therefore difficult to uphold if active aeolian alteration of grains in today's surface environment is taken into consideration. Several experimental studies have shown how chemical and mineralogical changes can also be induced by physical grain-grain interactions, for example by the interaction of oxidising radicals at fresh fracture surfaces with other soil constituents (Fubini et al., 1989; Merrison et al., 2010). Other studies have shown pseudochemical alterations from grain impacts as a function of grain shape and impact speed (Marshall et al., 2012), suggesting that the evolution of grains from vesicular to well-rounded will favour such effects. The discussion here aims to draw attention to the notion that the silicic spectral signature of weathered basaltic glasses can be best explained by a continuous alteration process that still takes place today. The most probable mechanism may be found in the dynamics of saltation impacts from aeolian reworking over geologic time, rather than an isolated period of (aqueous) leaching. Future experimental work will be required to reconcile the present-day spectral signatures of these unique outcrops with wind-induced grain alteration. Such studies can encompass grain impact experiments as outlined in this work using pristine and (artificially) leached basaltic glass grains from, for example, Iceland or Hawaii.

\section{Sequestered volatiles in volcanic glass}

Aeolian alteration mainly affects the exterior of a particle. With the exception of coarse sand grains, the interior of the most saltation-capable fraction (100-300 $\mu \mathrm{m}$ ) will remain intact for significant periods of time. This glass grain interior therefore preserves a valuable and quantifiable record of the formative condition of glaciovolcanic glass grains. Pressure solubility curves of volatiles sequestered (i.e. dissolved) in the glass matrix have been correlated to the confining cavity pressures (e.g. Fig. 2) as an effective tool for inferring palaeo-ice thicknesses (Tuffen et al., 2010; Owen et al., 2012). Analyses by the CheMin XRD instrument on the NASA Mars Curiosity rover indicated that $27 \pm 14 \%$ of the local regolith was composed of amorphous component, indicative of basaltic volcanic glass 

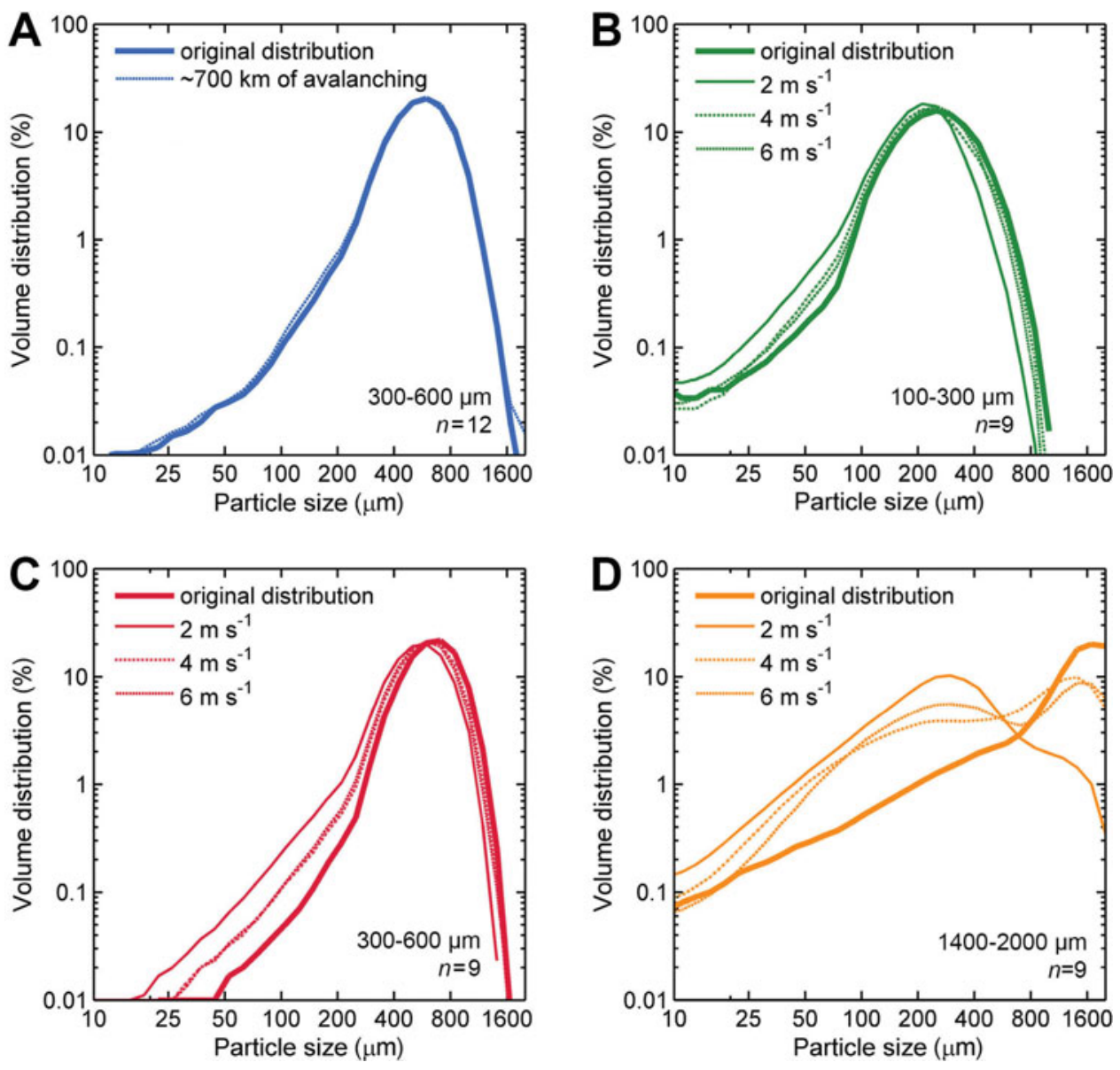

Fig. 7. Particle alteration in different aeolian energy regimes. A. Rolling and granular avalanching has little effect on the granulometry after $\sim 700 \mathrm{~km}$ of avalanching (data from: de Vet et al., 2014a). In contrast, grain-grain impacts during saltation are effective in changing the granulometry of sediments sieved at (B) 100-300 $\mu \mathrm{m},(C)$ 300-600 $\mu \mathrm{m}$ and (D) 1400-2000 $\mu \mathrm{m}$, and drive the evolution of the original particle size distribution towards a smaller mean particle size. In each of the graphs $B-D$ the accumulated grain impact kinetic energy (i.e. the aeolian energy) is comparable for each of the plotted wind speed treatments.

(Bish et al., 2013). Notable emissions of water during pyrolysis for these samples were found at temperatures of $150-450^{\circ} \mathrm{C}$, and were mainly ascribed to emission of water from the amorphous component of the regolith (Leshin et al., 2013). The association of water with fine-grained glass therefore underlines the potential of using sequestered volatiles in Martian glasses for inferring eruption conditions, as glasses formed by glaciovolcanism, subaerial eruptions and impacts will have distinctly different volatile signatures. The application of inferring, for example, palaeo-ice thicknesses from volatiles sequestered in glass-rich sediments is within reach of the current state-of-art of lander instrumentation suites and future developments such as Rahman-LIBS (e.g. Hooischuur et al., 2015).

\section{Relation of fragmental volcanic glass to habitability}

Glaciovolcanism has been proposed as one of the possible habitable niches in past Martian environments (Boston et al., 1992;
Cousins \& Crawford, 2011; Cousins et al., 2013), while others have shown how microorganisms can effectively occupy geothermal glacial refugia for survival of glaciations here on Earth (Fraser et al., 2014). The unique conditions provided by the interaction of erupting magma with surface or subsurface ices, the production of large quantities of liquid water and heat, and the occurrence of such environments across a vast range of latitudes and geologic episodes may have been exploitable by extinct or extant life on Mars (Cousins \& Crawford, 2011). Fragmental volcanic glass is directly associated with these environments and now forms a distinct geologic unit at the surface; making landforms composed of these materials a viable resource for the detection of habitable conditions. Several studies have targeted bioalteration processes of glass (e.g. Thorseth et al., 1992, 1995; Torsvik et al., 1998; Alt \& Mata, 2000). In an experimental study of bioalteration of basaltic glass from Surtsey, silicic rinds of $\sim 1 \mu \mathrm{m}$ thickness developed from microbial leaching of the grain exterior (Thorseth et al., 1995). The physical and chemical characteristics of these rinds are generally 
comparable to those formed by abiotic leaching (Minetti et al., 2007; Chemtob et al., 2010; Seelos et al., 2010), although it would go too far to tie biotic process to the silicic spectral properties observed on Mars. More importantly, the process of bioalteration illustrates how basaltic glass can act as an accessible substrate for microorganisms due to the bioavailability of nutrients in the glass structure. Assessing the preservation of bioalteration features, and as such biosignatures of extinct or extant life, starts with understanding the constraints imposed by aeolian reworking of sand grains.

\section{Conclusions}

Glaciovolcanic glass is a unique material that occupies a distinct niche in planetary geoscience due to its relation with palaeoclimatic conditions and its abundance on the surface of Mars. The difficulty of constraining the material's properties using present-day orbital platforms favours the use of terrestrial geologic substitutes in experiments to characterise their geomorphic behaviour in Mars' surface environment. Large outcrops composed of weathered basaltic glass are currently present in the form of dune fields of the sand seas of the northern lowlands on Mars. The mobilisation of these materials by surface winds underlines how glass grains are continuously subjected to grain alteration by saltation impacts. Experiments simulating transport processes in the dune cycle illustrate that particle impacts can alter particle size distributions, which foster a positive feedback loop where aeolian sediments evolve from coarse-grained to fine-grained, making it in turn possible to detach these grains and trigger saltation at lower (and more frequently recurring) surface wind speeds. Aeolian reworking of sediment also drives the removal of micrometre-think rinds from a particle's exterior. The preservation of the silicic signature after aeolian reworking over appreciable geologic time therefore suggests that a physicochemical alteration process is needed to retain such signatures until the present day. Volatiles sequestered in the glass structure left untouched by exterior alterations may provide a powerful proxy in the future for quantifying physical proxies of the material's formative conditions, which is within reach of present-day surface explorer technology. Volcanic glasses are also the most abundant geologic remnant from putative habitable niches in past environments. The preservation and removal of biosignatures of biotic interactions from these materials therefore awaits further experimental exploration.

\section{Acknowledgements}

This work stems from the author's PhD dissertation research, which was funded by the Institute for Biodiversity and Ecosystem Dynamics and supervised by Professor Karsten Kalbitz and Dr Erik Cammeraat. Wind tunnel experiments were performed in cooperation with Jon Merrison using the Marslab wind tunnel facilities at Aarhus University (Denmark). Facilities for sediment analyses were provided by the VU University Amsterdam and were supported by Martine Hagen. My special thanks go to Jochem Braakhekke (avalanching experiments) and Marloes Offringa (particle vortex chamber experiments) for their enthusiastic contribution to the data acquisition during their thesis research projects.

\section{References}

Allen, C.C., 1979. Volcano-ice interactions on Mars. Journal of Geophysical Research 84: 8048-8059.

Allen, C.C., Gooding, J.L., Jercinovic, I.M. \& Keil, K., 1981. Altered basaltic glass: A terrestrial analog to the soil of Mars. Icarus 45: 347-369.

Alt, J.C. \& Mata, P., 2000. On the role of microbes in the alteration of submarine basaltic glass: a TEM study. Earth and Planetary Science Letters 181: 301-313.

Bish, D.L., Blake, D.F., Vaniman, D.T., Chipera, S.J., Morris, R.V., Ming, D.W., Treiman, A.H., Sarrazin, P., Morrison, S.M., Downs, R.T., Achilles, C.N., Yen, A.S., Bristow, T.F., Crisp, J.A., Morookian, J.M., Farmer, J.D., Rampe, E.B., Stolper, E.M. Spanovich, N. \& MSL Science Team, 2013. X-ray Diffraction Results from Mars Science Laboratory: Mineralogy of Rocknest at Gale Crater. Science 341: 6153. doi: 10.1126/science.1239505.

Blake, D.F., Morris, R.V., Kocurek, G., Morrison, S.M., Downs, R.T., Bish, D., Ming, D.W., Edgett, K.S., Rubin, D., Goetz, W., Madsen, M.B., Sullivan, R., Gellert, R., Campbell, I., Treiman, A.H., McLennan, S.M., Yen, A.S., Grotzinger, J., Vaniman, D.T., Chipera, S.J., Achilles, C.N., Rampe, E.B., Sumner, D., Meslin, P.-Y., Maurice, S., Forni, O., Gasnault, O., Fisk, M., Schmidt, M., Mahaffy, P., Leshin, L.A., Glavin, D., Steele, A., Freissinet, C., Navarro-González, R., Yingst, R.A., Kah, L.C., Bridges, N., Lewis, K.W., Bristow, T.F., Farmer, J.D., Crisp, J.A., Stolper, E.M., Des Marais, D.J., Sarrazin, P. \& MSL Science Team, 2013. Curiosity at Gale Crater, Mars: Characterization and analysis of the Rocknest sand shadow. Science 341: 6153. doi: $10.1126 /$ science.1238932.

Boston, P.J., Ivanov, M.V. \& McKay, C.P., 1992. On the possibility of chemosynthetic ecosystems in subsurface habitats on Mars. Icarus 95: 300-308.

Bourke, M.C., Edgett, K.S. \& Cantor, B.A. 2008. Recent aeolian dune change on Mars. Geomorphology 94: 247-255.

Bourke, M.C., Lancaster, N., Fenton, L.K., Parteli, E.J.R., Zimbelman, J.R. \& Radebaugh, J., 2010. Extraterrestrial dunes: An introduction to the special issue on planetary dune systems. Geomorphology 121: 1-14.

Bridges, N.T., Bourke, M.C., Geissler, P.E., Banks, M.E., Colon, C., Diniega, S., Golombek, M.P., Hansen, C.J., Mattson, S., McEwen, A.S., Mellon, M.T., Stantzos, N. \& Thomson, B.J., 2012a. Planet-wide sand motion on Mars. Geology 40: 31-34.

Bridges, N.T., Ayoub, F., Avouac, J-P., Leprince, S., Lucas, A. \& Mattson, S. 2012b. Earth-like sand fluxes on Mars. Nature 485: 339-342.

Carrozzo, F.G., Altieri, F., Bellucci, G., Poulet, F., D'Aversa, E. \& Bibring, J.-P., 2012. Iron mineralogy of the surface of Mars from the $1 \mathrm{~mm}$ band spectral properties. Journal of Geophysical Research 117: E00J17. doi: 10.1029/2012JE004091. 
Chapman, M.G., Hare, T.M., Russell, A.J. \& Gudmundsson, M.T., 2003. Possible Juventae Chasma subice volcanic eruptions and Maja Valles ice outburst floods on Mars: Implications of Mars Global Surveyor crater densities, geomorphology, and topography. Journal of Geophysical Research 108(E10): 5113. doi: 10.1029/2002JE002009.

Chemtob, S.M., Jolliff, B.L., Rossman, G.R., Eiler, J.M. \& Arvidson, R.E., 2010. Silica coatings in the Ka'u Desert, Hawaii, a Mars analog terrain: A micromorphological, spectral, chemical, and isotopic study. Journal of Geophysical Research 115: E04001. doi: 10.1029/2009JE003473.

Chojnacki, M., Burr, D.M., Moersch, J.E. \& Michaels, T.I., 2011. Orbital observations of contemporary dune activity in Endeavor crater, Meridiani Planum, Mars. Journal of Geophysical Research 116: E00F19. doi: 10.1029/2010JE003675.

Cousins, C.R. \& Crawford, I.A., 2011. Volcano-ice interaction as a microbial habitat on Earth and Mars. Astrobiology 11: 695-710. doi: 10.1089/ast.2010.0550.

Cousins, C.R., Crawford, I.A., Carrivick, J.L., Gunn, M., Harris, J., Kee, T.P., Karlsson, M., Carmody, L., Cockell, C., Herschy, B. \& Joy, K.H., 2013. Glaciovolcanic hydrothermal environments in Iceland and implications for their detection on Mars. Journal of Volcanology and Geothermal Research 256: 61-77. doi: 10.1016/j.jvolgeores.2013.02.009.

de Vet, S.J., Mittelmeijer-Hazeleger, M.C., Braakhekke, J.J.M. \& Cammeraat, L.H., 2014a. Physical weathering and fracturing of a rhyolitic hyaloclastite in Iceland. Bulletin of Volcanology 76(833). doi: 10.1007/s00445-014-0833-7.

de Vet, S.J., Merrison, J.P., van Loon, E.E., Mittelmeijer-Hazeleger, M.C. \& Cammeraat, L.H., 2014b. Effects of rolling on wind-induced detachment thresholds of volcanic glass on Mars. Planetary Space Science 103: 205-218. doi: 10.1016/j.pss.2014.07.012.

Eshel, G., Levy, G.J., Mingelgrin, U. \& Singer, M.J., 2004. Critical evaluation of the use of laser diffraction for particle-size distribution analysis. Soil Science Society of America Journal 68: 736-743.

Fagan, A.L., Sakimoto, S.E.H. \& Hughes, S.S., 2010. Formation constraints on Matian north polar volcanic edifeces. Journal of Geophysical Research 115: E07013. doi: 10.1029/2009JE003476.

Fenton, L.K., 2006. Dune migration and slip face advancement in the Rabe Crater dune field, Mars, Geophysical Research Letters 33: L20201. doi:10.1029/2006GL027133.

Fraser, C.I., Terauds, A., Smellie, J., Convey, P. \& Chown, S.L., 2014. Geothermal activity helps life survive glacial cycles. PNAS 111(15): 5634-5639. doi: 10.1073/pnas.1321437111.

Fubini, B., Giamello, E. \& Volante, M., 1989. The possible role of oxygen species in quartz pathogenicity. Inorganic Chimica Acta 162: 187-189.

Gardina, E., Allemanda, P., Quantina, C., Silvestro, S. \& Delacourt, C., 2012. Dune fields on Mars: Recorders of a climate change? Planetary Space Science 60: 314-321.

Ghatan, G.J. \& Head, J.W., 2002. Candidate subglacial volcanoes in the south polar region of Mars: Morphology, morphometry, and eruption conditions. Journal of Geophysical Research 107: 1-21.

Goetz, W., Pike, W.T., Hviid, S.F., Madsen, M.B., Morris, R.V., Hecht, M.H., Staufer, U., Leer, K., Sykulska, H., Hemmig, E., Marshall, J., Morookian, J.M., Parrat, D., Vijendran, S., Bos, B.J., El Maarry, M.R., Keller, H.U., Kramm, R., Markiewicz, W.J., Drube, L., Blaney, D., Arvidson, R.E., Bell III, J.F., Reynolds, R., Smith, P.H., Woida, P., Woida, R. \& Tanner, R., 2010. Microscopy analysis of soils at the Phoenix landing site, Mars: Classification of soil particles and description of their optical and magnetic properties. Journal of Geophysical Research 115: E00E22. doi:10.1029/2009JE003437.

Greeley, R. \& Iversen, J.D., 1985. Wind as a Geological Process on Earth, Mars and Venus. Cambridge Planetary Science Series. Cambridge University Press (Cambridge).

Greeley, R. Iversen, J.D. \& Pollack, J.B., 1974. Wind tunnel studies of Martian Aeolian processes. Proceedings of the Royal Society London 341: 331-360.

Greeley, R., Leach, R., White, B.R., Iversen, J.D. \& Pollack, J.B., 1980. Threshold windspeeds for sand on Mars - Wind-tunnel simulations. Geophysical Research Letters 7: 121-124.

Hansen, C.J., Bourke, M., Bridges, N.T., Byrne, S., Colon, C., Diniega, S., Dundas, C., Herkenhoff, K., McEwen, A., Mellon, M., Portyankina, G. \& Thomas, N., 2011. Seasonal erosion and restoration of Mars' northern polar dunes. Science 331: 575-578.

Head III, J.W. \& Wilson, L., 2007. Heat transfer in volcano-ice interactions on Mars: Synthesis of environments and implications for processes and landforms. Annals of Glaciology 45: 1-13.

Hooijschuur, J.H., Verkaaik, M.F.C., Davies, G.R. \& Ariese, F. 2015. Will Raman meet bacteria on Mars? An overview of the optimal Raman spectroscopic techniques for carotenoid biomarkers detection on mineral backgrounds. Netherlands Journal of Geosciences. Available on CJ02015. doi:10.1017/njg.2015.3.

Horgan, B. \& Bell, J.F. 2012a. Widespread weathered glass on the surface of Mars. Geology 40: 391-394. doi: 10.1130/G32755.1.

Horgan, B.H.N. \& Bell III, J.F. 2012b. Seasonally active slipface avalanches in the north polar sand sea of Mars: Evidence for a wind-related origin. Geophysical Research Letters 39: L09201. doi:10.1029/2012GL051329.

Hovius, N., Lea-Cox, A. \& Turowski, J.M., 2008. Recent volcano-ice interaction and outburst flooding in a Mars polar cap re-entrant. Icarus 197: 24-38.

Ibrahim, A.H., Brach, R.M. \& Dunn, P.F., 2004. Microparticle detachment from surfaces exposed to turbulentair flow: microparticle motion after detachment. Journal of Aerosol Sciences 35: 1189-1204. doi:10.1016/j.jaerosci.2004.05.003.

Ibrahim, A.H., Dunn, P.F. \& Qazi, M.F., 2008. Experiments and validation of a model for microparticle detachment from a surface by turbulentair flow. Journal Aerosol Science 39: 645-656.

Iversen, J.D. \& White, B.R., 1982. Saltation threshold on Earth, Mars and Venus. Sedimentology 29: 111-119.

Iversen, J.D., Pollack, J.B., Greeley, R. \& White, B.R., 1976. Saltation threshold on Mars: effects of interparticle force, surface roughness and low atmospheric density. Icarus 29: 381-393.

Jakobsson, S.P., 1978. Environmental factors controlling the palagonitization of the Surtsey tephra, Iceland. Bulletin of the Geological Society of Denmark 27: 91-105.

Jakobsson, S.P. \& Gudmundsson, M.T., 2008. Subglacial and intraglacial volcanic formations in Iceland. Jökull 58: 179-196.

Jakobsson, S.P. \& Moore, J.G., 1986. Hydrothermal minerals and alteration rates at Surtsey volcano, Iceland. Geological Society of America Bulletin 97: 648659.

Jarosch, A., Gudmundsson, M.T., Högnadóttir, T. \& Axelsson, G., 2008. Progressive cooling of the hyaloclastite ridge at Gjálp, Iceland, 1996-2005. Journal of Volcanology and Geothermal Research 170: 218-229.

Keszthelyi, L.P., Jaeger, W.L., Dundas, C.M., Martinez-Alonso, S., McEwen, A.S. \& Milazzo, M.P., 2010. Hydrovolcanic features on Mars: Preliminary 
observations from the first Mars year of HiRISE imaging. Icarus 205: 211-229. doi: 10.1016/j.icarus.2009.08.020.

Kirkland, L.E., Herr, K.C. \& Adams, P.M., 2003. Infrared stealthy surfaces: Why TES and THEMIS may miss some substantial mineral deposits on Mars and implications for remote sensing of planetary surfaces. Journal of Geophysical Research 108(E12): 5137. doi: 10.1029/2003JE002105.

Kok, J.F., 2010a. An improved parameterization of wind-blown sand flux on Mars that includes the effect of hysteresis. Geophysical Research Letters 37: L12202. doi: 10.1029/2010GL043646.

Kok, J.F., 2010b. Difference in the wind speeds required for initiation versus continuation of sand transport on Mars: implications for dunes and dust storms. Physical Review Letters 104: 074502. doi: 10.1103/PhysRevLett.104.074502.

Kok, J.F., Parteli, E.J.R., Michaels, T.I. \& Karam, D.B., 2012. The physics of wind-blown sand and dust. Reports in Progress in Physics 7510: 106901. doi: 10.1088/0034-4885/75/10/106901.

Kokkelaar, B.P. \& Durant, G.P., 1983. The submarine eruption and erosion of Surtla (Surtsey), Iceland. Journal of Volcanology and Goethermal Research 19: 239-246. doi:10.1016/0377-0273(83)90112-9.

Komatsu, G., Ori, G.G., Ciarcelluti, P. \& Litasov, Y.D., 2004. Interior layered deposits of Valles Marineris, Mars: analogous subice volcanism related to Baikal Rifting, Southern Siberia. Planetary Space Science 52: 167-187.

Leshin, L.A., Mahaff, P.R., Webster, C.R., Cabane, M., Coll, P., Conrad, P.G., Archer Jr., P.D., Atreya, S.K., Brunner, A.E., Buch, A., Eigenbrode, J.L., Flesch, G.J., Franz, H.B., Freissinet, C., Glavin, D.P., McAdam, A.C., Miller, K.E., Ming, D.W., Morris, R.V., Navarro-González, R., Niles, P.B., Owen, T., Pepin, R.O., Squyres, S., Steele, A., Stern, J.C., Summons, R.E., Sumner, D.Y., Sutter, B., Szopa, C., Teinturier, S., Trainer, M.G., Wray, J.J., Grotzinger, J.P. \& MSL Science Team, 2013. Volatile, isotope, and organic analysis of martian fines with the Mars Curiosity Rover. Science 341: 6153. doi: 10.1126/science.1238937.

Licciardi, J.M., Kurz, M.D. \& Curtice, J.M., 2007. Glacial and volcanic history of Icelandic table mountains from cosmogenic $3 \mathrm{He}$ exposure ages. Quarternary Science Review 26: 1529-1546.

Marshall, J.R., Bull, P.A. \& Morgan, R.M., 2012. Energy regimes for aeolian sand grain surface textures. Sediment Geology 253-254: 17-24. doi: 10.1016/j.sedgeo.2012.01.001.

Martinez-Alonso, S., Mellon, M.T., Banks, M.E., Keszthelyi, L.P., McEwen, A.S. \& the HiRISE team, 2011. Evidence of volcanic and glacial activity in Chryse and Acidalia Planitiae, Mars. Icarus 212: 597-562. doi: 10.1016/j.icarus.2011.01.004.

Merrison, J.P., Gunnlaugsson, H.P., Nørnberg, P., Jensen, A.E. \& Rasmussen, K.R., 2007. Determination of the wind induced detachment threshold for granular material on Mars using wind tunnel simulations. Icarus 191: 568580.

Merrison, J.P., Bechtold, H., Gunnlaugsson, H., Jensen, A., Kinch, K., Nørnberg, P. \& Rasmussen, K., 2008. An environmental simulation wind tunnel for studying aeolian transport on Mars. Planetary Space Science 56: 426-437.

Merrison, J.P., Gunnlaugsson, H.P., Jensen, S.K. \& Nørnberg, P., 2010. Mineral alteration induced by sand transport: A source for the reddish color of martian dust. Icarus 205: 716-718. doi: 10.1016/j.icarus.2009.09.004.

Merrison, J.P., Gunnlaugsson, H.P., Hogg, M.R., Jensen, M., Lykke, J.M., Madsenc, M. Bo., Nielsen, M.B., Nørnberg, P., Ottosen, T.A., Pedersen, R.T., Pedersen, S. \& Sørensen, A.V., 2011. Factors affecting the electrifica- tion of wind-driven dust studied with laboratory simulations. Planetary Space Science 60: 328-335.

Minitti, M. E., Weitz, C.M., Lane, M.D. \& Bishop, J.L., 2007. Morphology, chemistry, and spectral properties of Hawaiian rock coatings and implications for Mars. Journal of Geophysical Research 112: E05015. doi: 10.1029/2006JE002839.

Moore, J.G. \& Calk, L.C. 1991. Degassing and differentiation in intraglacial volcanoes, Iceland. Journal of Volcanology and Geothermal Research 46: 157-180.

Neukum, G., Basilevsky, A.T., Kneissl, T., Chapman, M.G., van Gasselt, S., Michael, G., Jaumann, R., Hoffmann, H. \& Lanze, J.K., 2010. The geologic evolution of Mars: Episodicity of resurfacing events and ages from cratering analysis of image data and correlation with radiometric ages of Martian meteorites. Earth and Planetary Science Letters 294: 204-222.

Owen, J., Tuffen, H. \& McGarvie, D.W., 2012. Using dissolved H2O in rhyolitic glasses to estimate palaeo-ice thickness during a subglacial eruption at Bláhnúkur Torfajökull, Iceland. Bulletin of Volcanology 74: 1355-1378. doi: 10.1007/s00445-012-0601-5.

Pedersen, G.B.M., Head, J.W. \& Wilson, L., 2010. Formation, erosion and exposure of early Amzonian dikes, dike swarms and possible subglacial eruptions in the Elysium Rise/Utopia Basin Region, Mars. Earth and Planetary Science Letters 294: 424-439.

Reeks, M.W. \& Hall, D., 2001. Kinetic models for particle resuspension in turbulent flows: theory and measurments. Journal of Aerosol Science 32: 1-31.

Russel, J.K., Edwards, B.R., Porritt, L. \& Ryane, C., 2014. Tuyas: a descriptive genetic classification. Quarternary Science Review 87: 70-81. doi: 10.1016/j.quascirev.2014.01.001.

Scanlon, K.E., Head, J.W., Wilson, L. \& Marchant, D.R., 2014. Volcano-ice interactions in the Arsia Mons tropical mountain glacier deposits. Icarus 237: 315-317. doi: 10.1016/j.icarus.2014.04.024.

Seelos, K.D., Arvidson, R.E., Jolliff, B.L., Chemtob, S.M., Morris, R.V., Ming, D.W. \& Swayze, G.A., 2010. Silica in a Mars analog environment: Ka'u Desert, Kilauea Volcano, Hawaii. Journal of Geophysical Research 115: E00D15. doi: 10.1029/2009JE003347.

Silvestro, S., Fenton, L.K., Vaz, D.A., Bridges, N.T. \& Ori, G.G., 2010. Ripple migration and dune activity on Mars: Evidence for dynamic wind processes. Journal of Geophysical Research Letters 37: L20203. doi:10.1029/2010GL044743.

Silvestro, S., Vaz, D.A., Fenton, L.J. \& Geissler, P.E., 2011. Active aeolian processes on Mars: A regional study in Arabia and Meridiani Terrae. Geophysical Research Letters 38: L20201. doi:10.1029/2011GL048955.

Smellie, J.L., 2006. The relative importance of supraglacial versus subglacial meltwater escape in basaltic subglacial tuya eruptions: An important unresolved conundrum. Earth Science Review 74: 241-268.

Smellie, J.L., 2007. Quaternary volcanism: subglacial landforms. In: Elias, S.A. (ed.): Encyclopedia of Quaternary Sciences. Elsevier (Amsterdam): pp. 784798.

Sullivan, R., Banfield, D., Bell III, J.F., Calvin, W., Fike, D., Golombek, W., Greeley, R., Grotzinger, J., Herkenhoff, K., Jerolmack, D., Malin, M., Ming, D., Soderblom, L.A., Squyres, S.W., Thompson, S., Watters, W.A., Weitz, C.M. \& Yen, A., 2005. Aeolian processes at the Mars Exploration Rover Meridiani Planum landing site. Nature 436: 58-61.

Sullivan, R., Arvidson, R., Bell III, J.F., Gellert, R., Golombek, M., Greeley, R., Herkenhoff, K., Johnson, J., Thompson, S., Whelley, P. \& Wray, J., 2008. Wind-driven particle mobility on Mars: Insights 
from Mars Exploration Rover observations at "El Dorado" and surroundings at Gusev Crater. Journal of Geophysical Research 113: E06S07. doi: 10.1029/2008JE003101.

Thorseth, I.H., Furnes, H. \& Heldal, M., 1992. The importance of microbiological activity in the alteration of natural basaltic glass. Geochimica et Cosmochimica Acta 56: 845-850.

Thorseth, I.H., Furnes, H. \& Tumyr, O., 1995. Textural and chemical effects of bacterial activity on basaltic glass: an experimental approach. Chemical Geology 119: 139-160.

Torsvik, T, Funres, H., Muehlenbachs, K., Thorseth, I.H. \& Tumyr, O., 1998. Evidence for microbial activity at the glass-alteration interface in oceanic basalts. Earth and Planetary Science Letters 162: 165176.

Tuffen, H., 2007. Models of ice melting and edifice growth at the onset of subglacial basaltic eruptions. Journal of Geophysical Research 112: B03203. doi: 10.1029/2006JB004523.
Tuffen, H. , Owen, J. \& Denton, J., 2010. Magma degassing during subglacial eruptions and its use to reconstruct palaeo-ice thickness. Earth Science Review 99: 1-18.

van Bemmelen, R.W. \& Rutten, M.G., 1955. Table mountains of northern Iceland. E.J. Brill (Leiden): $217 \mathrm{pp}$.

Wilson, L. \& Head, J.W., 2002. Heat transfer and melting in subglacial basaltic volcanic eruptions: implications for volcanic deposit morphology and meltwater volumes. In: Smellie, J.L. \& Chapman, M.G. (eds): Volcano-Ice Interaction on Earth and Mars. Geological Society, London, Special publications 202: pp 5-26.

Zealey, W.J., 2009. Glacial, periglacial and glacio-volcanic structures on the Echus plateau, upper Kasei Valles. Planetary Space Science 57: 699-710.

Zuber, M.T., Phillips, R.J., Andrews-Hanna, J.C., Asmar, S.W., Konopliv, A.S., Lemoine, F.G., Plaut, J.J., Smith, D.E. \& Smrekar, S.E., 2007. Density of Mars' south polar layered deposits. Science 137: 1718-1719. doi: 10.1126/science.1146995. 